\title{
An Exhaustive Analysis of Stress on Faculty Members Engaged in Higher Education
}

\author{
Ankur Singh Bist ${ }^{1}$, Bhupesh Rawat ${ }^{2}$, Untung Rahardja ${ }^{3}$, Qurotul Aini ${ }^{4}$, Anggy Giri \\ Prawiyogi ${ }^{5}$
}

Faculty of Computer Science and Engineering ${ }^{1}$, Faculty of Computer Applications ${ }^{2}$, Master of Information Technology ${ }^{34}$, Faculty of Teacher Training and Education ${ }^{34}$ Graphic Era Hill University ${ }^{12}$, University of Raharja ${ }^{34}$, Buana Perjuangan Karawang University ${ }^{5}$ Road Society Area, Oghal Bhatta, Clement Town, Dehradun, Uttarakhand $248002^{1,2}$ Jl. Jenderal Sudirman No.40, RT.002/RW.006, Cikokol, Kec. Tangerang, Kota Tangerang, Banten $15117^{3,4,5}$

Jl Ronggo Waluyo Sirnabaya, Puseurjaya, Kec. Telukjambe Tim., Kabupaten Karawang, Jawa

To cite this document:

Bist, A. S. ., Rawat, B. ., Rahardja, U. ., Aini, Q., \& Prawiyogi, A. G. . (2022). An Exhaustive Analysis of Stress on Faculty Members Engaged in Higher Education. IAIC Transactions on Sustainable Digital Innovation (ITSDI), 3(2), 126-135.

Retrieved from https://aptikom-journal.id/index.php/itsdi/article/view/533

DOI: https://doi.org/10.34306/itsdi.v3i2.533

\begin{abstract}
Higher education is the face of innovation for any country. The quality and dedication of professors help to maintain quality in this process. With time, parameters were raised to check the quality of professor attributes. In this paper, we discuss all possible parameters taken by universities to evaluate faculty performance. Gradually it grew overhead pressure on professors and impacted the teaching-learning process. Our paper focused on stress parameters with possible solutions for the same issue. The process consists of several parameters to evaluate an employee's performance, such as no publications in conferences and journals, no patents filed, additional responsibilities performed, other qualifications achieved, result in the analysis of courses taught, etc. Still, it also puts a lot of pressure on both of them because they have to balance all this extra work and teaching. This paper focuses on different faculty assessment parameters and their impact on the faculty teachinglearning process. We also propose possible solutions on how this stress can be alleviated, and the existing strategy can be simplified.
\end{abstract}

Keywords: FDP, MDP, Performance metrics, University culture, Performance Management Software

\section{Introduction}

In higher education, faculty assessment is an important part of an academic process that is followed by all colleges and universities worldwide to maintain the quality of education, and it also serves as the basis for raising perks and promoting faculty [1][2][3][4]. This process is carried out yearly by an academic institution [5]. The process consists of several parameters to evaluate the performance of an employee, such as no of publications in conferences and 
journals, no of patents filed, additional responsibilities performed, other qualifications achieved, results in the analysis of courses taught, no of FDP (faculty development program) attended, no of the guest lecture delivered, no of the seminar followed, workshop organized, no of books published among others. Although this process is good to know about how an employee is performing within an organization and about the productivity of an employee [6][7][8][9][10], however, it also creates a lot of stress and pressure on the faculty as they have to balance all these additional works along with teaching [1][11]. All of this leads to performance degradation in the quality of education since a faculty can perform better if they focus on a single thing at a time [12]. Moreover, we understand and appreciate the significance of the additional work, i.e., research, etc. we suggest that this process be more straightforward. For this, we propose some solutions which result in improving research as well as the teaching-learning process [13][14][15][16]. Furthermore, we also suggest a few faculty performance management software that can be used for performance reviews, appraisal, and continuous feedback and helps in making the evaluation process simpler [17].

This paper focuses on different faculty assessment parameters and their impact on the faculty teaching-learning process. We also propose possible solutions on how this stress can be alleviated, and the existing strategy can be simplified [18][19].

This paper is organized as follows: Firstly, we discuss different parameters used to evaluate an employee'semployee's performance in an organization. Secondly, we focus on how these parameters/processes negatively impact the teaching-learning process and the faculty'sfaculty's stress level. Then we propose a few workable solutions to simplify the faculty evaluation process, which leads to a reduction in an employee's stress level. Finally, we suggest some performance management software to manage the evaluation process efficiently [20][21].

\section{Faculty Performance Index}

The following is a table of API Score (Maximum API Score:100, Minimum Required API:70 required)

\section{PART A}

A. General Information:

\begin{tabular}{|c|c|c|c|}
\hline Name: & & & \\
\hline Designation: & & & \\
\hline Department: & & & \\
\hline Qualification: & & & \\
\hline Area of Expertise: & & & \\
\hline & In Institution: & & \\
\hline & In Present Post: & & \\
\hline Experience (In Years) & At Previous Institution & $\begin{array}{l}\text { At Present } \\
\text { Institution }\end{array}$ & Total \\
\hline & & & \\
\hline
\end{tabular}

PART B. ACADEMIC PERFORMANCE INDICATORS (APIS) 


\section{CATEGORY I: TEACHING, LEARNING AND EVALUATION RELATED ACTIVITIES (65)}

B. Additional Teaching Workload (5):

(Other than Regular Teaching Workload: Per Week --> Theory: One period (1Point), Lab: Two periods (1 Point))

\begin{tabular}{|c|c|c|c|c|}
\hline S. No. & Class \& Course & $\begin{array}{c}\text { Total number of lectures } \\
\text { Allocated }\end{array}$ & $\begin{array}{c}\text { Self- appraisal } \\
\text { Score }\end{array}$ & $\begin{array}{c}\text { Verified API } \\
\text { Score }\end{array}$ \\
\hline 1 & & & & \\
\hline 2 & & & & \\
\hline \multicolumn{2}{|c|}{ Total } & & & \\
\hline
\end{tabular}

C. Course File \& Material/Lab Manual Completion (20):

(For each Theory Course file (4), Theory Material (10), Lab Course file (2), Lab Manual (4))

\begin{tabular}{|c|c|c|c|}
\hline S. No. & Class \& Course & Total number of lectures Allocated & Verified API Score \\
\hline 1 & & & \\
\hline 2 & & & \\
\hline \multicolumn{2}{|c|}{ Total } & & \\
\hline
\end{tabular}

D. Student Feedback (20):

(Feedback Scales:1-10, Points: Scale x 2))

\begin{tabular}{|c|c|c|c|}
\hline S. No. & Class \& Course & Total number of lectures Allocated & Verified API Score \\
\hline 1 & & & \\
\hline 2 & & & \\
\hline \multicolumn{2}{|c|}{ Total } & & \\
\hline
\end{tabular}

E. Results (20):

(If the pass \% is above 90, it's 20 Points, else if the average of pass percentage is ' $y$ ' for the last three years in a subject is taken as reference and performance will be evaluated. IF $x$ is current pass $\%$, then $x<y->0$ pts; $x=y->10 p t s ; x>=(y+5 \%)->15$ pts, otherwise -> 20pts)

\begin{tabular}{|c|c|c|c|c|c|}
\hline S. No. & $\begin{array}{c}\text { Class \& } \\
\text { Course }\end{array}$ & $\begin{array}{c}\text { Last 3 years } \\
\text { average pass \% }\end{array}$ & $\begin{array}{c}\text { Pass } \\
\text { Percentage }\end{array}$ & $\begin{array}{c}\text { Self- appraisal } \\
\text { Score }\end{array}$ & $\begin{array}{c}\text { Verified API } \\
\text { Score }\end{array}$ \\
\hline 1 & & & & & \\
\hline 2 & & & & & \\
\hline \multicolumn{2}{|c|}{ Total } & & & & \\
\hline
\end{tabular}


IAIC Transactions on Sustainable Digital Innovation (ITSDI)

Vol. 3 No. 2 April 2022

Score for Category I

\begin{tabular}{|c|c|c|c|}
\hline S. No. & Maximum API Score & API Score obtained & Remarks \\
\hline B & 5 & & \\
\hline C & 20 & & \\
\hline D & 20 & & \\
\hline E & 20 & & \\
\hline
\end{tabular}

CATEGORY II: PROFESSION - RELATED CONTRIBUTION (20)

F. Additional Responsibilities (5):

(Need to submit the detailed report on your additional work)

\begin{tabular}{|c|c|c|c|}
\hline S. No. & Nature of Role & Self- appraisal Score & Verified API Score \\
\hline 1 & & & \\
\hline 2 & & & \\
& & & \\
\hline \multicolumn{2}{|c|}{ Total } & 2 & \\
\hline
\end{tabular}

G. Memberships (5):

(For each professional membership (1 Points))

\begin{tabular}{|c|c|c|c|}
\hline S. No. & Organization & Self- appraisal Score & Verified API Score \\
\hline 1 & & & \\
\hline \multicolumn{2}{|c|}{ Total } & & \\
\hline
\end{tabular}

H. Workshops/FDPs/Conferences Attended as a Participant or Resource person (10) YYear:

(For each day 1 Point for participant and 2 points for resource person)

\begin{tabular}{|c|c|c|c|c|}
\hline S. No. & $\begin{array}{c}\text { Workshop/FDP/ } \\
\text { Conference Name }\end{array}$ & No. of days & Self- appraisal Score & Verified API Score \\
\hline 1 & & & & \\
\hline 2 & & & & \\
\hline \multicolumn{2}{|c|}{ Total } & & & \\
\hline
\end{tabular}


Score for Category II

\begin{tabular}{|c|c|c|c|}
\hline S. No. & Maximum API Score & API Score obtained & Remarks \\
\hline F & 5 & & \\
\hline G & 5 & & \\
\hline H & 10 & & \\
\hline
\end{tabular}

CATEGORY III: RESEARCH AND RELATED CONTRIBUTIONS (15)

I. Publications/Reviewer (10)

(International Journal/Book (5), National Journal (4), International Conference (3), National Conference (2), Article in any magazines (2), Reviewer (2))

\begin{tabular}{|c|c|c|c|c|}
\hline S. No. & Title & Type & Self- appraisal Score & Verified API Score \\
\hline 1 & & & & \\
\hline \multicolumn{2}{|c|}{ Total } & & \\
\hline
\end{tabular}

J. Funded Projects (Ongoing/Completed) (5)

(For each Project (5))

\begin{tabular}{|c|c|c|c|c|}
\hline S. No. & Title & $\begin{array}{c}\text { Sanctioned } \\
\text { Organization }\end{array}$ & $\begin{array}{c}\text { Self- appraisal } \\
\text { Score }\end{array}$ & Verified API Score \\
\hline 1 & & & & \\
\hline \multicolumn{3}{|c|}{ Total } & & \\
\hline
\end{tabular}

Score for Category III

\begin{tabular}{|c|c|c|c|}
\hline S. No. & Maximum API Score & API Score obtained & Remarks \\
\hline I & $\mathbf{1 0}$ & & \\
\hline J & 5 & & \\
\hline
\end{tabular}

Summary of API Scores

\begin{tabular}{|c|c|c|c|}
\hline Category & Criteria & $\begin{array}{c}\text { Last Academic Year } \\
\text { API Score }\end{array}$ & $\begin{array}{c}\text { Total API Score for } \\
\text { the Assessment } \\
\text { periode 2016-17 }\end{array}$ \\
\hline I & $\begin{array}{c}\text { TEACHING, LEARNING } \\
\text { AND EVALUATION } \\
\text { RELATED ACTIVITIES }\end{array}$ & & \\
\hline II & PROFESSION - RELATED & & \\
\hline
\end{tabular}




\begin{tabular}{|c|c|l|l|}
\hline & CONTRIBUTION & & \\
\hline \multirow{2}{*}{ III } & $\begin{array}{c}\text { RESEARCH AND } \\
\text { RELATED } \\
\text { CONTRIBUTIONS }\end{array}$ & & \\
& Total & & \\
\hline & & & \\
\hline
\end{tabular}

List of Enclosures:

1.

3.

5.

\section{Recommendations (From Experts):}

2.

4.

6.

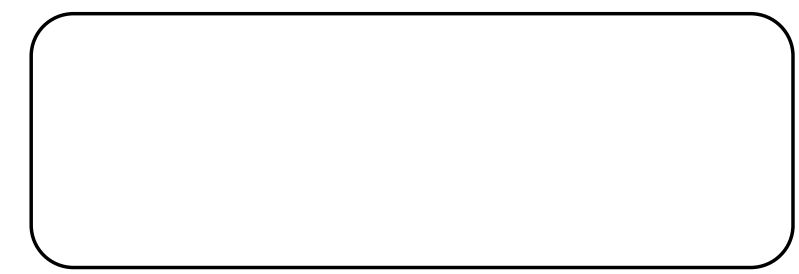

Signature of the Faculty Signature of HOD

Signature of the with designation and date

Principal with date

\section{Impact of Excessive Pressure on Faculty Performance}

In this section, we discuss how additional load such as research work [22][23], project work, and many other departmental responsibilities create stress which results in degradation of faculty's performance and disrupts students' learning [24][25].

The research includes publications in Scopus indexed conferences and journals, which takes a considerable amount of time from writing to publishing a paper. Moreover, if a faculty is pursuing a $\mathrm{PhD}$, it also involves intensive work that must be completed within the given timeline. A faculty also requires taking up projects which involve intensive fieldwork, which means arranging lectures which also affects students' learning process [26][27].

Furthermore, NAAC accreditation is mandatory for higher learning institutes, particularly state universities, to get UGC grants and financial aid [28]. NAAC assesses the higher learning institutes based on the following parameters or indicators: teaching-Learning \& Evaluation, Infrastructure \& Learning Resources, Research, Innovations \& Extension, Curricular Aspects, Student Support \& Progression.NAAC awards different grading to different universities based on their performance on the parameters mentioned above. This grade is 
crucial for a university as getting a good grade, such as $\left(A_{++}\right)$, ensures that the university is most sought after by the students, which enhances its reputation as well in general [29][30].

In this paper, we argue that research activities should be encouraged in any college or university; however, there should be dedicated faculties for carrying out project work and research work. This will result in dual benefits to all the parties involved, particularly the university, students, and faculty [31]. Another benefit would be that a faculty would deliver the teaching task better, learners would also excel in their subjects, and research output would be much better. For example, in some of the reputed institutes such as IIT and NIT [32], it is mandatory to publish one SCl paper in a year which seems infeasible sometimes given the amount of time taken to publish an SCI paper. In addition to this, faculties are also required to attend webinars and workshops, among others, and teach [33].

First, these bodies sought data on research and others from universities' research deans, who ask faculty to submit the same in a specified period. The data is collected monthly, which often causes huge amounts of redundant data. Look at this from a faculty point of view or perspective. You will find that a faculty has to manage so many things besides teaching, such as preparing a timetable in case a faculty is assigned the role of timetable coordinator, conducting the exam in case a faculty is given the responsibility of exam coordinator [34].

Many times, a faculty load of 28 hours a week, including theory and practical, demands more commitment and time [35]. Because of this, it is not possible to give enough time to research and other activities [5][6].

After discussion with several faculty members [36], we have found that it is not feasible for a faculty member to strike a balance between teaching and other commitments, as already mentioned. While making balance, faculty creates a lot of stress, which affects teaching performance, severely affecting results [37].

\section{Research, academic dishonesty, and other malpractice}

In the academic world, pressure increases to become good on all parameters, as mentioned in previous sections [38]. There are major areas where professors/lecturers have to give output. It may be classified as:

1. Academics

2. Research

3. Managerial Activities

Expectations of college/universities are increasing, and they want to make faculty good in all domains. It gave rise to the tendency to find false ways to get the objectives [35][36][39]. In the news, we have seen to get a good API or reputation in peer society, they put false information in research papers and make it publish [9]. Sometimes academicians use ghostwriters and third-party help to add their names to papers and patents [39]. It's due to survival tendency and the desire to get fame by unfair means [40]. Various research studies have been published [37] to analyze the pattern of self-citations by professors/researchers to get fame and visibility. Even journals and conference series are running for this malpractice. Further, it has been observed that the academic and research community is serious about self-citations, so some research groups have started to cite papers of each other again. They are doing it to increase their citation number.

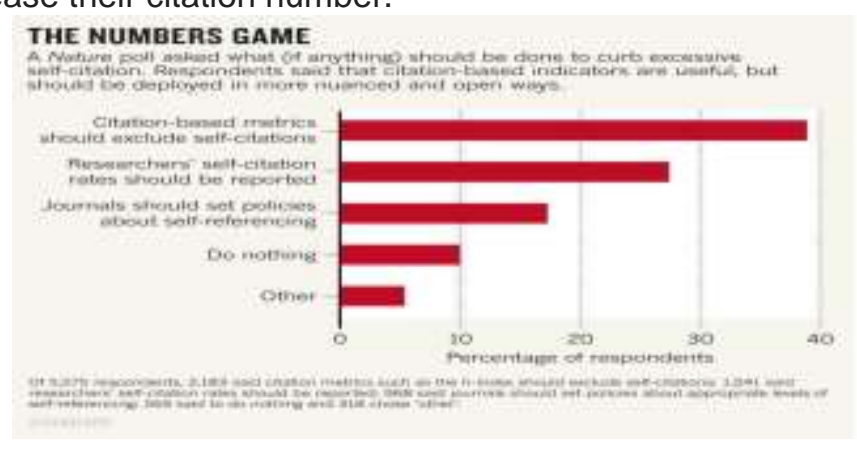

Figure1: Number Game of Citations 


\section{Conclusion}

This paper focuses on peer pressure handled by professors and junior faculty members in the university system. Performance evaluation patterns are given on paper. To fulfill the needs, we mentioned paths of dishonesty taken by professors. Our objective is to open a thread to avoid these malpractices in the education industry. In the future, we are planning to make an analysis based on feedback systems from university professors across the globe.

This process is carried out yearly by an academic institution. The process consists of several parameters to evaluate the performance of an employee, such as no of publications in conferences and journals, no of patents filed, additional responsibilities performed, additional qualifications achieved, result in the analysis of courses taught, no of FDP (faculty development program) attended, no of a guest lecture delivered, no of the seminar attended, workshop organized, no of books published among others Although this process is good to know about how an employee is performing within an organization. However, an employee's productivity also creates a lot of stress and pressure on the faculty as they have to balance all this additional work and teaching.

In this paper, we argue that research activities should be encouraged in any college or university; however, there should be dedicated faculties for carrying out project work and research work. This will result in dual benefits to all the parties involved, particularly the university, students, and faculty.

\section{References}

[1] G. Abramo, C. A. D'Angelo, and L. Grilli, "The effects of citation-based research evaluation schemes on self-citation behavior," arXiv Prepr. arXiv2102.05358, 2021.

[2] E. Peebles, M. Scandlyn, and B. R. Hesp, "A retrospective study investigating requests for self-citation during open peer review in a general medicine journal," PLOS One, vol. 15, no. 8, p. e0237804, 2020.

[3] M. O. Adeoti, F. M. Shamsudin, and A. M. Mohammad, "Opportunity, job pressure and deviant workplace behaviour: does neutralisation mediate the relationship? A study of faculty members in public universities in Nigeria," Eur. J. Manag. Bus. Econ., 2020.

[4] T. Hariguna, U. Rahardja, and Q. Aini, "Effect of social media activities to determinants public participate intention of e-government," Procedia Comput. Sci., vol. 161, pp. 233241, 2019.

[5] E. A. Nabila, S. Santoso, Y. Muhtadi, and B. Tjahjono, "Artificial Intelligence Robots And Revolutionizing Society In Terms Of Technology, Innovation, Work And Power," IAIC Trans. Sustain. Digit. Innov., vol. 3, no. 1, pp. 46-52, 2021.

[6] A. S. Anwar, U. Rahardja, A. G. Prawiyogi, and N. P. L. Santoso, "iLearning Model Approach in Creating Blockchain Based Higher Education Trust," Int. J. Artif. Intell. Res., vol. 6, no. 1, 2022.

[7] M. N. A. Azman, S. A. Permana, P. Jana, and M. A. Al Muhsin, "The online publishing strategies in improving the higher education institution ranking: A case study of PGRI University of Yogyakarta," Pegem J. Educ. Instr., vol. 12, no. 1, pp. 193-198, 2022.

[8] G. Maulani, E. W. Musu, Y. J. W. Soetikno, and S. Aisa, "Education Management using Blockchain as Future Application Innovation," IAIC Trans. Sustain. Digit. Innov., vol. 3, no. 1 , pp. 60-65, 2021.

[9] N. F. Rozy, R. Ramadhiansya, P. A. Sunarya, and U. Rahardja, "Performance Comparison Routing Protocol AODV, DSDV, and AOMDV with Video Streaming in Manet," in 2019 7th International Conference on Cyber and IT Service Management (CITSM), 2019, vol. 7, pp. 1-6.

[10] R. Widayanti, U. Rahardja, F. P. Oganda, M. Hardini, and V. T. Devana, "Students Formative Assessment Framework (Faus) Using the Blockchain," in 2021 3rd International Conference on Cybernetics and Intelligent System (ICORIS), 2021, pp. 16.

[11] U. Rahardja, M. Hardini, A. L. Al Nasir, and Q. Aini, "Taekwondo sports test and training data management using blockchain," in 2020 Fifth International Conference on 
Informatics and Computing (ICIC), 2020, pp. 1-6.

[12] T. F. Toimah, Y. I. Maulana, and I. Fajar, "Gamification Model Framework and its Use in E-Learning in Higher Education," IAIC Trans. Sustain. Digit. Innov., vol. 3, no. 1, pp. 28-35, 2021.

[13] M. J. E. Urlings, B. Duyx, G. M. H. Swaen, L. M. Bouter, and M. P. Zeegers, "Citation bias and other determinants of citation in biomedical research: findings from six citation networks," J. Clin. Epidemiol., vol. 132, pp. 71-78, 2021.

[14] U. Rahardja, Q. Aini, M. D. A. Ngadi, M. Hardini, and F. P. Oganda, "The Blockchain Manifesto," in 2020 2nd International Conference on Cybernetics and Intelligent System (ICORIS), 2020, pp. 1-5.

[15] D. Julianingsih, A. G. Prawiyogi, E. Dolan, and D. Apriani, "Utilization of Gadget Technology as a Learning Media," IAIC Trans. Sustain. Digit. Innov., vol. 3, no. 1, pp. 43-45, 2021.

[16] E. M. Haryono, I. Gunawan, A. N. Hidayanto, and U. Rahardja, "Comparison of the ELT vs ETL Method in Data Warehouse Implementation: A Qualitative Study," in 2020 International Conference on Informatics, Multimedia, Cyber and Information System (ICIMCIS), 2020, pp. 115-120.

[17] S. S. Alhat, "Understanding Revised NAAC Grading Pattern," Int. J. Arts, Sci. Humanit., vol. 8, no. 1, pp. 57-60, 2020.

[18] A. B. Fitra, A. Suharko, F. M. Albar, and D. Apriliasari, "Examination Of Customer Interest In The Use Of The Mandiri Syariah Mobile Application At PT. Bank Syariah Mandiri Bekasi Branch Office," IAIC Trans. Sustain. Digit. Innov., vol. 3, no. 2, pp. 110 125, 2022.

[19] U. Rahardja, "Decision Support System for Ranking of Students in Learning Management System (LMS) Activities using Analytical Hierarchy Process (AHP) Method," in Journal of Physics: Conference Series, 2020, vol. 1477, no. 2, p. 22022.

[20] D. F. Feldon, "Cognitive load and classroom teaching: The double-edged sword of automaticity," Educ. Psychol., vol. 42, no. 3, pp. 123-137, 2007.

[21] Q. Aini, M. Yusup, N. P. L. Santoso, A. R. Ramdani, and U. Rahardja, "Digitalization Online Exam Cards in the Era of Disruption 5.0 using the DevOps Method," J. Educ. Sci. Technol., vol. 7, no. 1, pp. 67-75, 2021.

[22] D. Apriani, A. Williams, U. Rahardja, A. Khoirunisa, and S. Avionita, "The Use of Science Technology In Islamic Practices and Rules In The Past Now and The Future," Int. J. Cyber IT Serv. Manag., vol. 1, no. 1, pp. 48-64, 2021.

[23] R. J. Sipahutar, A. N. Hidayanto, U. Rahardja, and K. Phusavat, "Drivers and Barriers to IT Service Management Adoption in Indonesian Start-up Based on the Diffusion of Innovation Theory," in 2020 Fifth International Conference on Informatics and Computing (ICIC), 2020, pp. 1-8.

[24] A. Faturahman, V. Agarwal, and C. Lukita, "Blockchain Technology-The Use Of Cryptocurrencies In Digital Revolution," IAIC Trans. Sustain. Digit. Innov., vol. 3, no. 1, pp. 53-59, 2021.

[25] M. Prawira, H. T. Sukmana, V. Amrizal, and U. Rahardja, "A Prototype of AndroidBased Emergency Management Application," in 2019 7th International Conference on Cyber and IT Service Management (CITSM), 2019, vol. 7, pp. 1-6.

[26] P. Edastama, N. Lutfiani, U. Rahardja, S. Avionita, and P. A. Sunarya, "Overview of Business Innovation and Research Probability on Blockchain and Introduction to its Exclusive Version," in 2021 3rd International Conference on Cybernetics and Intelligent System (ICORIS), 2021, pp. 1-7.

[27] Z. Fauziah, H. Latifah, U. Rahardja, N. Lutfiani, and A. Mardiansyah, "Designing Student Attendance Information Systems Web-Based," Aptisi Trans. Technopreneursh., vol. 3, no. 1, pp. 23-31, 2021.

[28] E. J. Russell and I. K. Weigold, "Work Stress and Comfort in University Faculty: Do Gender and Academic Field Matter?," J. Employ. Couns., vol. 57, no. 3, pp. 130-142, 2020.

[29] R. Craig, A. Cox, D. Tourish, and A. Thorpe, "Using retracted journal articles in psychology to understand research misconduct in the social sciences: What is to be 
done?," Res. Policy, vol. 49, no. 4, p. 103930, 2020.

[30] S. P. J. M. Horbach, E. Breit, W. Halffman, and S.-E. Mamelund, "On the willingness to report and the consequences of reporting research misconduct: the role of power relations," Sci. Eng. Ethics, vol. 26, no. 3, pp. 1595-1623, 2020.

[31] R. Dal-Ré, L. M. Bouter, P. Cuijpers, C. Gluud, and S. Holm, "Should research misconduct be criminalized?," Res. Ethics, vol. 16, no. 1-2, pp. 1-12, 2020.

[32] D. Tourish and R. Craig, "Research misconduct in business and management studies: Causes, consequences, and possible remedies," J. Manag. Inq., vol. 29, no. 2, pp. 174-187, 2020.

[33] J. Crombie, "Medical ghost-and guest-writing as corrupt practices and how to prevent them," in Integrity, Transparency and Corruption in Healthcare \& Research on Health, Volume I, Springer, 2020, pp. 141-158.

[34] P. A. Sunarya, A. Williams, A. Khoirunisa, A. S. Bein, and D. M. Sari, "A Blockchain Based Online Business Intelligence Learning System," Blockchain Front. Technol., vol. 1, no. 01, pp. 87-103, 2021.

[35] S. A. Raza, W. Qazi, K. A. Khan, and J. Salam, "Social isolation and acceptance of the learning management system (LMS) in the time of COVID-19 pandemic: an expansion of the UTAUT model," J. Educ. Comput. Res., vol. 59, no. 2, pp. 183-208, 2021.

[36] A. Williams and E. Dolan, "Application of Blockchain Technology in e-LoA Technopreneurship Journal," Aptisi Trans. Technopreneursh., vol. 2, no. 1, pp. 98-103, 2020.

[37] Q. Aini, T. Hariguna, P. O. H. Putra, and U. Rahardja, "Understanding how gamification influences behaviour in education," Int. J. Adv. Trends Comput. Sci. Eng, vol. 8, no. 1.5, pp. 269-274, 2019.

[38] U. Rahardja and E. P. Harahap, "Implementation of Information Planning and Strategies Industrial Technology 4.0 to Improve Business Intelligence Performance on Official Site APTISI," in Journal of Physics: Conference Series, 2019, vol. 1179, no. 1, p. 12111.

[39] Q. Aini, A. Badrianto, F. Budiarty, A. Khoirunisa, and U. Rahardja, "Alleviate fake diploma problem in education using block chain technology," J. Adv. Res. Dyn. Control Syst, vol. 12, no. 2, pp. 1821-1826, 2020.

[40] A. I. L. Wibowo, A. D. Putra, M. S. Dewi, and D. O. Radianto, "Study of Divergence of Go Public Company's Financial Performance Based on Website Before and After Merger Using Window Period Method TIME Frame 2015-2017," Aptisi Trans. Technopreneursh., vol. 1, no. 1, pp. 27-51, 2019. 